\title{
Fair Value and Cost Accounting, Depreciation Methods, Recognition and Measurement for Fixed Assets
}

\author{
Anastasios Tsamis ${ }^{1}$, Konstantinos Liapis $^{2}$
}

\begin{abstract}
:
In accounting and finance, fair value is a rational and unbiased estimate of the potential market price of a good, service or asset. On the other hand, cost accounting policy is more conservative and prudence. Accounting fairness refers mostly to the fair presentation, the initial recognition and measurement or valuation of an element. Therefore, adopting different accounting policies results in the assets being presented in the entity's financial statements with different values. With the application of cost or fair value accounting policies across firms or countries, the financial statements are being incomparable.

Another issue arises from depreciation methods applied. With the application of different depreciation accounting methods across firms or countries, the financial statements are being incomparable. Both accounting policies for recognition and measurement and depreciation methods, determine the net value of fixed assets in financial statements' presentations.

Thus, a decision-making procedure exists for recognition and measurement of property assets using the above components. The research objects of the paper are to explore in detail the relationship between cost and fair value accounting policies with depreciation methods, by enabling decision-making options.

The financial method of discounted cash flow (DCF) technique is used for fair value accounting as well as for impairment test and the depreciation accounting methods are used for cost accounting policy, in order to explore the decision options for a property asset recognition and measurement.

Following the above procedure, a fair value accounting model is correlated with the deprecation methods and an analysis of the impact of each decision-making alternative in financial statements' figures is produced.
\end{abstract}

Key Words: Cost accounting; Fair value accounting; DCF; Depreciation methods;

\section{JEL Classification Codes: M41}

\footnotetext{
${ }^{1}$ Professor, Department of Public Administration, Panteion University of Social and Political Sciences, atsamis@panteion.gr

2 Assistant Professor, Department of Economic and Regional Development, Panteion University of Social and Political Sciences, konstantinos.liapis@panteion.gr
} 


\section{INTRODUCTION}

According to microeconomics, property is defined as a good able to provide a constant flow of services, such as housing services or a source of cash inflow. Assets are consumer durable goods held either by households for housing needs, or by firms in order to install their business activities necessary to operate. As goods traded in the market, asset prices are defined through the law of demand and supply. In markets under equilibrium current values must reflect the assets' present values taking into account the time value of money. Any variations from the valuation under present values leave space for moving from the equilibrium spot and the movement will continue until all current values reflect present values. Economics recognize the financial return of the asset by consumption or sale as a capital gain arising from the increase of the value of the asset. By establishing variable accounting treatments for assets, assets have developed into a prosperous investment tool for companies in order to obtain economic benefits, not only through consumption (own use) or sale, but also through investing. Accounting fairness refers mostly to the fair presentation - and therefore, measurement or valuation - of an element recognized in the entity's financial statements. According to the Generally Accepted Accounting Principles (GAAP) across countries, two basic methods exist for asset valuation: the accounting of fair value and the accounting of historical cost. Fair value is a rational and unbiased estimate of the potential market price of a good, service, or asset. It takes into account such objective factors as: acquisition/production/distribution costs, replacement costs, or costs of close substitutes; actual utility at a given level of development of social productive capability; supply vs. demand; and subjective factors such as risk characteristics; cost of and return on capital; and individually perceived utility. In accounting, fair value is used as a certainty of the market value of an asset (or liability) for which a market price cannot be determined (usually because there is no established market for the asset). Historical cost states that each financial effect of a realized transaction stated in the firm's financial position shall be recorded at acquisition cost. Applying different accounting methods across firms or countries makes financial statements incomparable to each other. Even within the International Financial Reporting Standards (IFRS) framework the choice between the two valuation models for certain asset portfolios is a given option. US GAAP, also seem to have a different approach in property valuation. Under US GAAP (FAS 157), fair value is the amount at which the asset could be bought or sold in a current transaction between willing parties, or transferred to an equivalent party, other than in a liquidation sale. The latest edition of the International Valuation Standards (2007), clearly distinguishes between fair value (as defined in the IFRS) and market value (as defined in the IVS): so, as the term is generally used, fair value can be clearly distinguished from market value. It requires the assessment of the price that is fair between two specific parties taking into account the respective advantages/disadvantages that each will gain from a transaction. Although market value may meet these criteria, this is not necessarily always the case. Fair value is frequently used when undertaking due diligence in corporate transactions, where 
particular synergies between the two parties may mean that the price that is fair between them is higher than the price that might be obtainable on the wider market. In other words, a special value may be generated. Market value requires this element of special value to be disregarded, but it forms part of the assessment of fair value.

Depreciation is the process of allocating costs to an asset over its entire useful life. This allocation is done in a way that the cost of the asset (depreciation expense) is charged to the accounting periods during the economic life of the asset and decreases the net value of fixed assets. Applying different depreciation accounting and valuation methods across firms or countries makes financial statements incomparable to each other.

The aim of the study is to explore the relationship between depreciation and discounted cash-flow (DCF) methodologies when these are applied to the valuation of fixed assets and how these methods correlate with each other. The methods are applied to a typical commercial property asset (an office building, as part of a property developer's fixed assets portfolio).

\section{THE ACCOUNTING FRAMEWORK FOR FIXED ASSETS}

Fixed assets are tangible assets used by a business to produce income like: buildings; plant; equipment; transportation means; machinery; computers; anything that will probably bring future economic benefits. Fixed assets share common characteristics: they are used in the production of business income; they have a useful economic life of at least one year; and they are used up or wear out over time. As accounting elements, assets are ruled by a set of basic aspects such as: cost (cost of land, construction cost, etc.), residual value, useful-life estimation and depreciation impact. The above elements are correlated with type and the use form of the asset. Asset accounting is subject to the accounting framework instituted by the Accounting Board of each country. The most famous Accounting Boards are the International Accounting Standards Board (IASB - IFRS, IAS) and the Financial Standards Board (FASB - US GAAP). Both the IASB and FASB aim to develop a set of high quality global accounting standards that require transparent and comparable information in general purpose financial statements. In pursuit of this objective, FASB and IASB co-operate with national accounting standard-setters to achieve convergence in accounting standards around the world. The accounting framework provides a general set of accounting principles. Some of the principles that apply to this study are: prudence; historical cost; substance over form; going concern; and true and fair view. Other principles and qualitative characteristics of the financial statements are: matching principle; accrual basis; understandability; relevance; materiality; reliability; faithful representation; comparability; neutrality; completeness; timeliness; materiality; cost and benefit balance and consistency. According to IFRS, fair value is the price at which the property could be exchanged between knowledgeable, willing parties in an arm's length transaction (IAS 40). According to US GAAP fair value is the price that would be received to sell an asset 
or paid to transfer a liability in an orderly transaction between market participants at the measurement date (FAS 157).

The accounting framework provides a general set of accounting principles. Some of the principles that apply to our study are: Prudence; Historical Cost; Substance over Form; Going Concern; and True and Fair View. Other principles and qualitative characteristics of the financial statements are: Matching Principle, Accrual basis, understandability, relevance, materiality, reliability, faithful representation, comparability, neutrality, completeness, timeliness, materiality, cost and benefit balance and consistency. Prudence or conservatism is a principle which is adopted by IFRS and US-GAAP and refers to the inclusion of a degree of caution in the exercise of the judgments needed in making the estimates required under uncertainty conditions (e.g. useful life of plant and equipment), so that assets or income are not overstated and liabilities or expenses are not understated. Conservatism is the asymmetry in the verification requirements for gains and losses. This interpretation allows for degrees of conservatism: the greater the difference in degree of verification required for gains versus losses, the greater the conservatism. According to Watts (2003) conservatism has benefits to parties associated with the firm. Specifically, conservative accounting is a means of addressing problems due to parties to the firm having asymmetric information, asymmetric payoffs and limited liability. For instance, shareholder litigation produces asymmetric payoffs: overstating net assets is more likely to generate litigation costs than understating net assets. Therefore conservatism, by understating net assets, reduces the firm's expected litigation costs. Historical cost is a basic accounting principle states that each financial effect of a realized transaction stated in the firm's financial position shall be recorded at acquisition cost, which is the amount of cash received or paid at the time of the transaction (e.g. market price of a building at purchase time). Substance over form is a US GAAP and IFRS principle. However, US GAAP and IFRS embrace the fact that faithful representation of accounting events permits that these events shall be accounted and presented with their substance and economic reality, which is not always consistent with their legal form. Going concern is a basic accounting principle accepted by the US GAAP, IRFSs. Under this principle it is assumed that the entity will continue to operate for the foreseeable future. True and fair view principle, applied mainly in US GAAP and IFRS, relates to the 'fair' presentation of the financial position, performance and changes in financial position of an entity. As will be demonstrated, 'fair' is a hard-to-define accounting principle, as the specification of 'fair' is highly subjective and differs across economic circumstances. Therefore a specific definition is a difficult case. However, US GAAP and IFRS provide a general definition, not much different between each other. According to IFRS Fair Value is the price at which the property could be exchanged between knowledgeable, willing parties in an arm's length transaction (IAS 40). According to US GAAP Fair Value is the price that would be received to sell an asset or paid to transfer a liability in an orderly transaction between market participants at the measurement date (FAS 157). 


\section{COST ACCOUNTING vs. FAIR VALUE ACCOUNTING PRINCIPLES}

Accounting fairness refers mostly to the fair presentation and, therefore, measurement or valuation of an element recognized in the entity's financial statements. According to the GAAP across the countries, two basic valuation methods exist under the estimate that the firm is under going concern: The accounting of fair value and the accounting of historical cost. Applying different accounting methods across firms or countries makes financial statements incomparable to each other. Even within the IFRS framework the choice between the two valuation models for certain asset portfolios is a given option. US GAAP, also seem to have a different approach in measuring property. The measurement method choice is of great importance because it affects the comprehensive income of the firm (income and shareholder's equity). Valuation of property results, therefore, to a change in financial statements. This result can directly affect contracts linked to accounting numbers, e.g. it can loosen the stranglehold of debt covenants and reduce the informational asymmetry. The accounting frameworks of US GAAP, IFRS and Greek GAAP differ with each other. US and Greek GAAP are more prudent in comparison to IFRS. Also, US and Greek GAAP are rule-based, while IFRS are principle-based. Therefore, IFRS leave decision choices to the management of the firm, while US GAAP set also numbered boundaries above or under which the accounting treatment methods change. IFRS comprise the most 'fair' approach, because they provide the choice of the presentation of financial statements at fair value, although calculation of fair value of fixed assets is a difficult issue which requires professional skills. The full convergence of the three studied accounting frameworks in a common-global framework is a challenge. The framework that is proposed shall use fair values, meaning values that will resemble economic reality at measurement dates, as much as possible, as the accounting valuation principle used to value fixed assets irrespectively of their use and their portfolio categorization (Thalassinos and Liapis, 2013). Revaluations shall affect the firm's equity special reserve by passing profit/loss, as unrealized gain or loss and shall be recycled to the firms' profit and loss only by realization, e.g. sale, disposal, destruction. Such a framework eliminates any motivations of the management to classify property in certain portfolios and prohibits the choice between avoiding and undertaking the risk of affecting the profit and loss account when revaluating assets. Therefore, profit becomes more prudent and balance sheet becomes more timely and relevant, resulting to uniformity of financial accounting and representation of fixed assets and succeeding comparability between firms and countries. According to IFRS, fixed assets must be tested for potential impairment of their value (impairment test - IAS 36) at least on each balance sheet date. Impairment may be evidenced either by market indications or by firm-specific indications. A market indication may be an increase in the interest rates or Real Estate market prices. A firm-specific indication - impairment trigger event - may be a fire-destruction of a manufactory building or a liquidity issue resulting to a re-assessment of the continuance of the operation of the firm. 


\section{Cost accounting vs. Fair value accounting principles}

Accounting fairness refers mostly to the fair presentation and, therefore, measurement or valuation of an element recognized in the entity's financial statements. According to the GAAP across countries, two basic valuation methods exist under the estimate that the firm is under going concern: the accounting of fair value and the accounting of historical cost (Freshfields Bruckhaus Deringer LLP, 2009; Missonier-Piera, 2007). Applying different accounting methods across firms or countries makes financial statements incomparable to each other. Even within the IFRS framework the choice between the two valuation models for certain asset portfolios is a given option. US GAAP, also seem to have a different approach in measuring property. The measurement method choice is of great importance because it affects the comprehensive income of the firm (income and shareholder's equity). Valuation of property results, therefore, to a change in financial statements. This result can directly affect contracts linked to accounting numbers, e.g. it can loosen the stranglehold of debt covenants and reduce the informational asymmetry. Lin and Peasnell (2000) point out the benefits and disadvantages associated with asset revaluation. The potential benefits include: the reduction of risk of violating accounting-based covenants as a result of a strengthened balance sheet; the provision of a credible signal of better prospects to come; and the reduction of the firm's reported accounting rate of return, improving its bargaining position. Among the potential disadvantages are the additional out-of-pocket costs (mainly the valuation fees paid to independent valuators) involved. According to the studied frameworks that refer to fair value revaluation of assets, IFRS give a more free and less specific definition about fair value, US GAAP (SFAS 157) provide a hierarchy of three levels of inputs in applying various valuation techniques. The fair-value hierarchy gives the highest priority to quoted prices in active markets for identical assets or liabilities (level 1) and the lowest priority to unobservable inputs (level 3). Level 1 is designated to quote prices for identical items in active, liquid and visible markets such as stock exchanges. Level 2 indicates observable information for similar items in active or inactive markets, such as prices for two similarly situated buildings in the same downtown real estate market. Level 3 marks unobservable inputs to be used in situations where markets do not exist or are illiquid. For an asset, a fair value measurement assumes the highest and best use of the asset by market participants. According to FSP FAS 157-3 fair value is a current exit value and may differ from a transaction price (entry price) due to different markets of purchase and sell, or bargain purchase options, or due to transaction prices including acquisition costs. Moreover, measurement must include assumptions about risk and uncertainty when pricing the asset. FSP 157-3 also highlights the need to consider the relevance of market data and environment, especially in the present credit squeeze, where fair value becomes highly subjective. Supporters of fair value assert that the revaluation of property, plant, and equipment improves forecasts of future earnings and provides greater feedback value and more timely information than historical cost measures (Herrmann et al., 2006). In addition, the predictive value of fair values over historical cost extends in situations as: the asset valuation of an entity which is no longer a going concern, the estimation of an acquisition price, the liquidation of the 
firm's assets. The number of fair value exceptions (instead of historical cost) already existing under US GAAP provides many examples whereby fair value measures are currently used in place of historical cost measures in the valuation of property, plant and equipment, such as: Assets subject to impairment are written down to fair value, donated property, plant, and equipment are measured at fair value as there is no historical cost alternative. Although fair values are assessed by professional experienced valuators, they include judgment and acceptances when estimating the fair value of property, so the estimates, at least to some degree, are subjective (Dietrich et al., 2001). Therefore, the level of subjectivity and uncertainty is greater than that in the case of historical cost. Some academics have also expressed reservations over fair value accounting following the perceived misuse of fair value accounting in some recent American accounting scandals (Watts, 2003). Also, fair value estimates are more likely to be relevant but less likely to be reliable in compare to historical cost (Dietrich et al., 2001). However, historical cost may under certain circumstances be also a defective measure of valuating assets, e.g. in cases where prices are not specified objectively (during inflation periods), and does not always comply with the principal of the timeliness of information. Both cost and fair value accounting incorporate advantages and disadvantages, under different situations and therefore both FASB and IASB provide alternative choices about the asset valuation adoption method. The gap between the market prices and the 'fair' values of the assets is today an important issue caused by the world financial crisis, the credit squeeze and the exceeding supply of assets. The adaptation debility of the market to the present economic environment which does not permit an equilibrium point of demand and supply has caused price warps and declination from 'fair' values.

\section{Accounting treatment for funding fixed assets}

A fixed asset can be acquired through various ways. The simpler acquisition method is the purchase with cash. When cash or cash equivalent is not available, the funding of fixed assets can be obtained through asset exchange transactions (IAS16 BC Property, Plant and Equipment), through borrowing (IAS 23 - Borrowing Costs), through grants (IAS 20 - Government Grants). Fixed assets can also be funded through stock issue when establishing a firm or with new capital stock issue or through acquirement or merger of other companies. It can also be funded by issuing corporate bonds. Finance or operating leasing is also a way of funding assets. Leasing is a famous asset acquiring method when cash acquisition is not possible. Another case of funding a fixed asset acquisition refers to sale and leaseback. Under IFRS Leasing is dealt by IAS 17.

\section{The use of fixed assets and accounting portfolio composition}

Fixed assets are elements of the financial position of the entity. According to IFRS, an asset is recognized only if it is probable that future economic benefits associated with the item will flow to the entity and the cost of the item can be reliably measured (IAS 16). Fixed assets can be used in many different ways in order to create future economic benefits for the entity, such as: the continuing use of fixed assets by the 
firm in order to operate; the construction and sale of fixed assets in the normal course of business; the lease of fixed assets in order to benefit from rentals; the investment in fixed assets made for capital appreciation; the purchase, manufacturing and subsequent sale made with bargain options, as trading transaction. Each portfolio has different features and accounting treatments for each kind of financial transaction and under different GAAPs (Herrmann et al., 2006). Following IFRS the portfolios for fixed assets are: Own Used Portfolio, Current Asset Portfolio, Held for Sale Portfolio, Investment Portfolio and a special treatment for fixed assets under Long Term Leasing.

The decision of the use intention, on the other hand, of a fixed asset at initial recognition is dependent of the key profitability metrics detection and measurement. The key profitability metrics of tangible assets are: (i) rent, (ii) the opportunity cost of not using the asset and (iii) any expected gain that will result from the valuation of property at 'fair' value. The measurement of profitability metrics is the basis for creating asset valuation models (discounted rentals, value in use, 'fair' observed market values). At initial recognition management should establish a purchase price allocation method, such as the one used when acquiring a company. According to the studied accounting frameworks, the cost of the asset recognized initially is the cash equivalent paid to acquire the asset. However, purchase price usually contains a bargain when acquiring commercial real estates. Also, it may contain a revaluation gain arising from the past use of the asset. So, the 'bare' value must be abstracted from any surplus value attached to the purchase price. The purchase price allocation should recognize the bare value in assets, while any surplus value should be transferred to equity reserve as gain from acquired assets. As an important investment and accounting tool, property requires both financial and accounting knowledge in order to be managed. Financial knowledge is necessary for the management to locate investments in property that will result to surplus values for the firm and accounting knowledge is the background of the appropriate classification and measurement of property, according to their use purpose.

The accounting frameworks of US GAAP, IFRS and Greek GAAP differ between each other. US and Greek GAAP are more prudent in compare to IFRS. Also, US and Greek GAAP are rule-based, while IFRS are principle-based. Therefore, IFRS leave decision choices to the management of the firm, while US GAAP set also numbered boundaries above or under which the accounting treatment methods change. IFRS comprise the most 'fair' approach, because they provide the choice of the presentation of financial statements at fair value, although calculation of fair value of fixed assets is a difficult issue which requires professional skills. The full convergence of the three studied accounting frameworks in a common-global framework is a challenge. The framework that is proposed shall use fair values, meaning values that will resemble economic reality at measurement dates, as much as possible, as the accounting valuation principle used to value fixed assets irrespectively of their use and their portfolio categorization. Revaluations shall affect the firm's equity special reserve by passing $\mathrm{P} / \mathrm{L}$, as unrealized gain or loss and shall 
be recycled to the firms' profit and loss only by realization, e.g. sale, disposal, destruction. Such a framework eliminates any motivations of the management to classify property in certain portfolios and prohibits the choice between avoiding and undertaking the risk of affecting the profit and loss account when revaluating assets. Therefore, profit becomes more prudent and balance sheet becomes more timely and relevant, resulting to uniformity of financial accounting and representation of fixed assets and succeeding comparability between firms and countries.

\section{DEPRECIATION METHODS FOR FIXED ASSETS}

The acquisition value for each fixed asset is generally measured by the cash outlay required to obtain the asset. Fixed assets are valued at actual cost or, if the cost is not readily determined, at estimated cost. Acquisition cost includes the purchase price or construction cost, as well as all costs incurred to place an asset in its intended location and in an operable condition. Such costs associated with an asset include: freight and transportation charges; installation costs; site preparation expenditures; professional fees (including title costs and surveying fees if appropriate); legal costs directly attributable to asset acquisition; and cost of necessary easements and right-of-ways (Peterson, 2002).

Depreciation is the process of allocating asset costs over its life. This allocation is done in a way that the cost of the asset (depreciation expense) is charged to the accounting periods during the economic life of the asset. The following are the purpose of charging depreciation of fixed assets: to ascertain the true profit of the business, to show the true presentation of financial position, to provide fund for replacement of assets and to show the asset at its reasonable value in the balance sheet. The following factors are to be considered while charging the amount of depreciation: the original cost of the asset; the useful life of the asset; and the estimated scrap or residual value of the asset at the end of its life. The Basic Asset Life-Cycle: an asset is acquired and added to the asset ledger; at the end of each period, depreciation expense for qualifying assets is recorded for each book; Journal entries are generated for the posting book to specified accounts in the General Ledger; at some point, ownership interest in the asset is relinquished and the asset is disposed. Depreciation accounting is helpful to ascertain the true profit and the real financial position of the entity. Accumulated depreciation is deducted from the related asset account on the balance sheet to compute the asset's book value (Thalassinos et al., 2015). The certain commonly used terms for depreciations are: Original cost of the asset is the cost incurred in making the asset available for use in the first instance; Salvage value is the expected recovery of the sales value of an asset at the end of its useful life; Useful life is the expected time period for which the asset provides economic services, that is, the period in which the asset could be used for an entity's production or operational activities; Depreciable cost is the original cost less expected salvage value. This is the amount of expenses the enterprise will be incurring on amount of expired costs of the machine over its useful or economic life; Written down value of an asset at any point of time is original cost less 
depreciation to date (i.e. accumulated depreciation). It is also referred to as book value. To assess depreciation, the accounting practice uses several criteria, such as: the economic life; the volume of activity produced; the interest rate, etc. The different depreciation methods aim to allocate the cost of an asset to different accounting periods in a systematic and rational manner. Each method produces a different pattern of expenses over time. In order to correct measuring of depreciation it is essential to know the conceptual meaning of depreciation, depletion and amortization: Depreciation is treated as a revenue loss which is recorded when expired utility fixed assets such as plant and machinery, building and equipment etc.; The term depletion refers to measure the rate of exhaustion of the natural resources or assets such as mines, iron ore, oil wells, quarries etc. While comparing with depreciation, depletion is generally applied in the case of natural resources to ascending the rate of physical shrinkage but in the case of depreciation is used to measure the fall in the value or utility of fixed assets such as plant and machinery and other general assets; The term amortization is applied in the case of intangible assets such as patents, copyrights, goodwill, trademarks etc., Amortization is used to measure the reduction in value of intangible assets; obsolescence means a reduction of usefulness of assets due to technological changes, improved production methods, change in market demand for the product or service output of the asset or legal or other restrictions (FAS Manual Depreciation, 2013).

The following are the various methods applied for measuring allocation of depreciation cost (Aston Manor Academy, 2012):

- Straight Line Method (SLM)

- Written Down Value (WDV) Method

- Annuity Method

- $\quad$ Sinking Fund Method (SFM)

- Revaluation or Appraisal Method

- Insurance Policy Method

- Depletion Method

- Sum of Years' Digits (SYD) Method

- Machine Hour Rate Method

\section{DEPRECIATION METHODS USED IN THE RESEARCH}

\subsection{Straight-Line Method (SLM)}

The straight-line method (SLM), also known as the fixed installment method, allocates an equal amount of an asset's cost to each year of its expected useful life. This allocation assumes that an equal amount of an asset's potential is consumed in each period of its life. However, this may not be true under all circumstances. The repairs and maintenance cost will be lower in earlier years of use but will gradually be higher as the asset becomes old. Moreover, the asset might have different capacities over different years of its life. The amount of depreciation for each period is computed by deducting the asset's expected residual value from its acquisition 
cost, and dividing the result by the assets expected economical and useful life. The rate of depreciation is the reciprocal of the estimated useful life. This may be presented as follows:

Annual Depreciation $=($ Cost of the Asset - Residual Value $) /($ Estimated Economic Life) or

Annual Depreciation $=($ Depreciation per Unit of Output $) \times$ (Number of Units Produced during an Accounting Period) where

Depreciation per Unit of Output $=($ Cost of Asset - Residual Value $) /($ Estimated Output during Economic Life)

\subsection{Written-Down Value (WDV) Method}

Under the written-down value (WDV) method of calculating depreciation, the amount charged for depreciation declines over the asset's expected life. This method is suitable in cases where: (a) the receipts are expected to decline, as the asset gets older; and (b) it is believed that the allocation of depreciation should be related to the pattern of asset's expected receipts. The WDV method is also known as the reducing, diminishing, or declining balance method. The depreciation charge is calculated by multiplying the net book value of the asset (acquisition cost less accumulated depreciation) at the start of each period by a fixed rate. Under the WDV method, it is impossible to reduce the asset value to zero, because there is always some balance to reduce the asset value even further. When the asset is sold, abandoned, or retired from use, the WDV appearing in books is written-off as depreciation for the final period. Under this method, the fixed depreciation rate used charges the acquisition cost less salvage or residual value of the asset over its service life:

$r=1-\sqrt[n]{\frac{s}{c}}=1-\left[-\frac{s}{c}\right]^{\frac{1}{n}}$

Where:

$r=$ Rate of depreciation or a fixed percentage

$\mathrm{n}=$ Number of years of asset's useful life

$\mathrm{s}=$ Salvage value or residual value

$\mathrm{c}=$ Acquisition cost of the asset

Depreciation at a certain rate is applied to the WDV of the asset as at the beginning of each year. The effect of this method is that the depreciation amount charged every year is an amount less than the previous year. In other words, larger amounts are charged to depreciation during the initial years of the asset's useful life.

\subsection{Sum-of-the-years'-digits (SYD) Method}

The sum-of-the-years'-digits (SYD) method of depreciation charges larger amount of asset costs to expenses in the early years of life, and lesser amount in later years. The depreciation is calculated by multiplying an asset's depreciable cost by a declining 
ratio derived from the sum of the number of years in the asset's expected life. To calculate the appropriate SYD ratio, first the sum of the digits in the expected life is found. For example, the SYD for an asset with a life of 5 years is calculated as $(5+$ $4+3+2+1)=15$. Next, the appropriate ratio for each year of the expected life is determined. Each balance year is divided figure by the sum of the digits (e.g., 5/15, $4 / 15 \ldots$ 1/15). Finally, the depreciable cost, that is the acquisition cost less the residual value, is multiplied by the ratio for each year to determine the annual depreciation. This method applies a changing rate to the depreciable cost which is constant, whereas the declining balance method applies a constant rate to a changing book value. The SYD Method is designed on the basis of Written-Down Value Method. Under this method the amount of depreciation to be charged to the Profit and Loss Account goes on decreasing every year throughout the life of the asset. The formula for calculating the amount of depreciation is as follows:

\section{Rate of Depreciation $=$ \\ $=\left(\frac{\text { Remaining_Life_of_the_Asset_(Including_current_year) }}{\text { Sum_of_all_the_digits_of_the_life_of_the_assets_in_years }}\right) x$ (Original Cost of the Asset)}

SYD depreciation is an accelerated depreciation method that allocates a greater percentage of the asset to early periods and a smaller percentage of the asset to later periods. The basic premise of this method is that as an asset ages, it begins to wear out, thus providing less value. SYD uses a formula to calculate the rate of depreciation. Unlike double-declining-balance, the rate of the SYD changes from each period and never switches to straight-line depreciation. The SYD is equal to $\mathrm{N}$ $(\mathrm{N}+1) / 2$ where $\mathrm{N}$ equals the asset's useful life.

\subsection{Sinking Fund Method}

The Annuity Method is most suitable for a firm where capital is invested in the least hold properties. Under this method, while calculating the amount of depreciation, a fixed amount of depreciation is charged for every year of the estimated useful life of the asset in such a way that at a fixed rate of interest is calculated on the same amount had been invested in some other form of capital investment. In other words, depreciation is charged for every year refers to interest losing or reduction in the original cost of the fixed assets. Under the annuity method where the loss of interest is due to the investment made in the form of an asset is considered while calculating the depreciation. Like the Annuity Method, the amount of depreciation is charged with the help of Sinking Fund Tables. Under this method an amount equal to the amount written off as depreciation is invested in outside securities in order to facilitate to replace the asset at the expiry useful life of the asset. In other words, the amount of depreciation charged is debited to depreciation account and an equal amount is credited to Sinking Fund Account. At the estimated expiry useful life of the asset, the amount of depreciation each year is invested in easily realizable securities which can be readily available for the replacement of the asset. 


\section{DISCOUNTED CASH-FLOW (DCF) AND FAIR VALUE ACCOUNTING}

According to the work of Liapis et al. (2014), the traditional NPV equation is transformed to a prototype DCF methodology introducing a number of variables that affect the valuation of fixed assets, after analysing a number of components like: the operating and net cash flows (OCF and NCF); the relationship between Price and Revenue of real property; the discount factor or Weighted Average Cost of Capital (WACC); tax rates; inflation and risk-free rates; risk premium; and expected capital gains. The analysis resulted in the development of an integrated DCF model based on the following mathematical expressions:

$$
\begin{aligned}
& \mathrm{NCF}_{\mathrm{t}}=\left[\left(\mathrm{R}_{\mathrm{t}}+\mathrm{RV}_{\mathrm{T}}\right)-\left(\mathrm{C}_{0}+\mathrm{O}_{\mathrm{t}}+\mathrm{M}_{\mathrm{t}}\right)\right] \cdot\left(1-\varphi_{\mathrm{t}}^{\mathrm{y}}\right) \\
& \mathrm{AC}_{\mathrm{t}}=\left[\left(\mathrm{i}_{\mathrm{FR}}-\varphi_{\mathrm{t}}^{\mathrm{p}}\right)\left(1-\varphi_{\mathrm{t}}^{\mathrm{y}}\right)+\delta_{\mathrm{t}}\right]
\end{aligned}
$$

$\mathrm{i}_{\mathrm{S}}=\exp \left(\frac{\ln 2 * \ln (1+\mathrm{g})}{\ln \left(\frac{\mathrm{AC} C_{\mathrm{t}}+\Lambda_{\mathrm{t}}}{\mathrm{AC} \mathrm{C}_{\mathrm{t}}+\Lambda_{\mathrm{t}}-\mathrm{g}}\right)}\right)-1$

(3)

WACC $=i_{D} \cdot\left(1-\varphi_{t}^{\mathrm{y}}\right) \cdot\left(\frac{\mathrm{D}}{\mathrm{D}+\mathrm{S}}\right)+\mathrm{i}_{\mathrm{S}} \cdot\left(\frac{\mathrm{s}}{\mathrm{D}+\mathrm{S}}\right)$

(4)

For any year ' $y$ ' of property life-cycle, the remaining Value of fixed asset is the sum of the (discounted) values of the NCFs from year ' $y$ ' until the end year ' $T$ ' of its useful life (UL):

Value $_{\mathrm{y}}=\sum_{\mathrm{t}=\mathrm{y}}^{\mathrm{T}} \frac{\mathrm{NCF}_{\mathrm{t}}\left(1-\varphi_{\mathrm{t}}^{\mathrm{p}}\right)}{(1+\mathrm{WACC})^{\mathrm{t}}}$

(5)

Where:

$\begin{array}{ll}\mathrm{NCF}_{\mathrm{t}} & : \text { Net cash-flow of the project at year } \mathrm{t} \\ \mathrm{t} & : 1, \ldots, \mathrm{T} \text { and } \mathrm{T}=\text { End year of } \mathrm{UL} \\ \mathrm{y} & : 1, \ldots \mathrm{y} \ldots, \mathrm{T} \text { any year of UL } \\ \mathrm{WACC} & : \text { The discount rate or the Weighted Average Cost of Capital } \\ \mathrm{R}_{\mathrm{t}} & : \text { Revenue (income) at year } \mathrm{t}, \\ \mathrm{RV}_{\mathrm{T}} & : \text { Residual value of fixed asst } \\ \mathrm{O}_{\mathrm{t}} & : \text { Operating costs at operating year } \mathrm{t} \\ \mathrm{M}_{\mathrm{t}} & : \text { Maintenance costs at operating year } \mathrm{t} \\ \varphi_{\mathrm{t}}^{\mathrm{y}} & : \text { Corporate tax rate, Income tax on property yield (annual rent) } \\ \mathrm{C}_{0} & : \text { Acquisition Cost } \\ \mathrm{NCC}_{0} & : \text { Acquisition Expenses } \\ \varphi_{\mathrm{t}}^{\mathrm{p}} & : \text { Property tax rate } \\ \mathrm{i}_{\mathrm{FR}} & : \text { Risk-free rate of interest, where: } \mathrm{i}_{\mathrm{FR}}=\mathrm{i}_{8}+\mathrm{i}_{\mathrm{int}}\end{array}$


$\mathrm{i}_{\text {s. }}$

$\mathrm{i}_{\text {inf }}$

$\delta_{\mathrm{t}}$

$\Lambda_{\mathrm{t}}$

$\mathrm{EG}_{\mathrm{t}+1}$

$\mathrm{AC}_{\mathrm{t}}$
: Risk-free rate of interest in an economy without inflation

: Inflation rate

: Rate of operating, maintenance, where: $\delta_{\mathrm{t}}=\frac{\left(\mathrm{O}_{\mathrm{t}}+\mathrm{M}_{\mathrm{t}}\right)}{\left(\mathrm{C}_{\mathrm{0}}+\mathrm{NCC}_{\mathrm{p}}\right)}$

: Risk premium, for commercial property investments

: Expected capital gains at year $\mathrm{t}+1$

: Direct cost of property asset which is equal to cost ratio exempt risk premium and capital gains, thus:

\section{ESTIMATIONS AND FINDINGS}

The research objective of the paper is a presentation of depreciation methods in comparison with DCF methodology. Both DCF and depreciation methods are applied to a typical commercial property asset - an office building, as part of a real property developer's fixed assets portfolio - in order to explore the relationship between these methods when applied to the valuation of fixed assets and how these methods correlate with each other. Using the above mentioned DCF methodology (Liapis et al., 2014), the assumptions and basic calculations are provided in the Table 1:

Table 1. DCF calculations - Office Building

\begin{tabular}{|c|c|c|c|c|}
\hline & $\begin{array}{c}\text { Quantity } \\
\text { Measure } \\
\text { (QM) }\end{array}$ & $\%$ & rates/QM & values \\
\hline Rev./year & 1.000 & 11,43 & 180,00 & 180.000 \\
\hline Acquisition Cost & 1.000 & & $1.500,00$ & 1.500 .000 \\
\hline Acquisition Expenses & 1.000 & $\%$ a. cost & $5,00 \%$ & 75.000 \\
\hline Operation Expenses & 1.000 & 1,27 & 20,00 & 20.000 \\
\hline Maintenance Expenses & 1.000 & 0,63 & 10,00 & 10.000 \\
\hline Residual Value & 1.000 & & $10 \%$ & 150.000 \\
\hline Period of acquisition & 30 & 10 & & \\
\hline Planning to sale & & 50 & & \\
\hline Total LC years of Asset & & 50 & & \\
\hline Tax on Income & $25,00 \%$ & & & \\
\hline Property Tax & $1,00 \%$ & & & \\
\hline
\end{tabular}


Fair Value and cost accounting, depreciation methods, recognition and measurement for fixed assets

\begin{tabular}{|c|c|}
\hline \multicolumn{2}{|l|}{ Finance } \\
\hline D & $\mathbf{S}$ \\
\hline $0,00 \%$ & $100,00 \%$ \\
\hline WACC & $7,25 \%$ \\
\hline Credit Spread & $3,00 \%$ \\
\hline Inflation Rate & $2,00 \%$ \\
\hline Free risk rate & $4,00 \%$ \\
\hline Risk Premium $\Lambda$ & $6,00 \%$ \\
\hline Growth Rate g & $0,10 \%$ \\
\hline Free risk rate $i^{*}$ & $2,00 \%$ \\
\hline
\end{tabular}

DCF and current accounting values per depreciation method are provided in Table 2 and DCF curves in Figure 1.

Table 2. Fixed Asset Value and current accounting values - Office Building

\begin{tabular}{|r|c|c|c|c|c|}
\hline Year & $\begin{array}{c}\text { Value } \\
\text { Fix.Asset }\end{array}$ & $\begin{array}{c}\text { Current Ac. } \\
\text { Value } \\
\text { (SLM) }\end{array}$ & $\begin{array}{c}\text { Current Ac. } \\
\text { Value } \\
\text { (WDV) }\end{array}$ & $\begin{array}{c}\text { Current Ac. } \\
\text { Current Ac. } \\
\text { Value (SYD) }\end{array}$ & $\begin{array}{c}\text { Value } \\
\text { (SFM) }\end{array}$ \\
\hline 10 & 1.650 .894 & 1.540 .244 & 1.487 .214 & 1.507 .143 & 1.568 .790 \\
\hline 11 & 1.675 .161 & 1.505 .488 & 1.404 .321 & 1.440 .941 & 1.562 .131 \\
\hline 12 & 1.699 .122 & 1.470 .732 & 1.326 .048 & 1.376 .394 & 1.554 .988 \\
\hline 13 & 1.722 .702 & 1.435 .976 & 1.252 .138 & 1.313 .502 & 1.547 .327 \\
\hline 14 & 1.745 .820 & 1.401 .220 & 1.182 .348 & 1.252 .265 & 1.539 .111 \\
\hline 15 & 1.768 .384 & 1.366 .463 & 1.116 .447 & 1.192 .683 & 1.530 .299 \\
\hline 16 & 1.790 .296 & 1.331 .707 & 1.054 .220 & 1.134 .756 & 1.520 .848 \\
\hline 17 & 1.811 .449 & 1.296 .951 & 995.461 & 1.078 .484 & 1.510 .712 \\
\hline 18 & 1.831 .724 & 1.262 .195 & 939.977 & 1.023 .868 & 1.499 .840 \\
\hline 19 & 1.850 .991 & 1.227 .439 & 887.585 & 970.906 & 1.488 .181 \\
\hline 20 & 1.869 .110 & 1.192 .683 & 838.114 & 919.599 & 1.475 .675 \\
\hline 21 & 1.885 .927 & 1.157 .927 & 791.400 & 869.948 & 1.462 .263 \\
\hline 22 & 1.901 .273 & 1.123 .171 & 747.289 & 821.951 & 1.447 .879 \\
\hline 23 & 1.914 .965 & 1.088 .415 & 705.638 & 775.610 & 1.432 .451 \\
\hline 24 & 1.926 .804 & 1.053 .659 & 666.308 & 730.923 & 1.415 .905 \\
\hline 25 & 1.936 .571 & 1.018 .902 & 629.169 & 687.892 & 1.398 .159 \\
\hline 26 & 1.944 .030 & 984.146 & 594.101 & 646.516 & 1.379 .126 \\
\hline 27 & 1.948 .922 & 949.390 & 560.988 & 606.794 & 1.358 .713 \\
\hline 28 & 1.950 .968 & 914.634 & 529.720 & 568.728 & 1.336 .819 \\
\hline
\end{tabular}




\begin{tabular}{|r|r|r|r|r|r|}
\hline 29 & 1.949 .861 & 879.878 & 500.195 & 532.317 & 1.313 .338 \\
\hline 30 & 1.945 .269 & 845.122 & 472.316 & 497.561 & 1.288 .155 \\
\hline 31 & 1.936 .833 & 810.366 & 445.990 & 464.460 & 1.261 .145 \\
\hline 32 & 1.924 .159 & 775.610 & 421.132 & 433.014 & 1.232 .177 \\
\hline 33 & 1.906 .822 & 740.854 & 397.659 & 403.223 & 1.201 .107 \\
\hline 34 & 1.884 .360 & 706.098 & 375.495 & 375.087 & 1.167 .786 \\
\hline 35 & 1.856 .270 & 671.341 & 354.566 & 348.606 & 1.132 .047 \\
\hline 36 & 1.822 .007 & 636.585 & 334.804 & 323.780 & 1.093 .718 \\
\hline 37 & 1.780 .981 & 601.829 & 316.143 & 300.610 & 1.052 .608 \\
\hline 38 & 1.732 .550 & 567.073 & 298.522 & 279.094 & 1.008 .518 \\
\hline 39 & 1.676 .017 & 532.317 & 281.883 & 259.233 & 961.231 \\
\hline 40 & 1.610 .630 & 497.561 & 266.172 & 241.028 & 910.514 \\
\hline 41 & 1.535 .568 & 462.805 & 251.336 & 224.477 & 856.120 \\
\hline 42 & 1.449 .947 & 428.049 & 237.327 & 209.582 & 797.782 \\
\hline 43 & 1.352 .805 & 393.293 & 224.099 & 196.341 & 735.214 \\
\hline 44 & 1.243 .101 & 358.537 & 211.609 & 184.756 & 668.108 \\
\hline 45 & 1.119 .707 & 323.780 & 199.814 & 174.826 & 596.136 \\
\hline 46 & 981.401 & 289.024 & 188.677 & 166.551 & 518.945 \\
\hline 47 & 826.860 & 254.268 & 178.161 & 159.930 & 436.157 \\
\hline 48 & 654.650 & 219.512 & 168.231 & 154.965 & 347.366 \\
\hline 49 & 463.219 & 184.756 & 158.854 & 151.655 & 252.136 \\
\hline 50 & 150.000 & 150.000 & 150.000 & 150.000 & 150.000 \\
\hline
\end{tabular}


Fair Value and cost accounting, depreciation methods, recognition and measurement for fixed assets

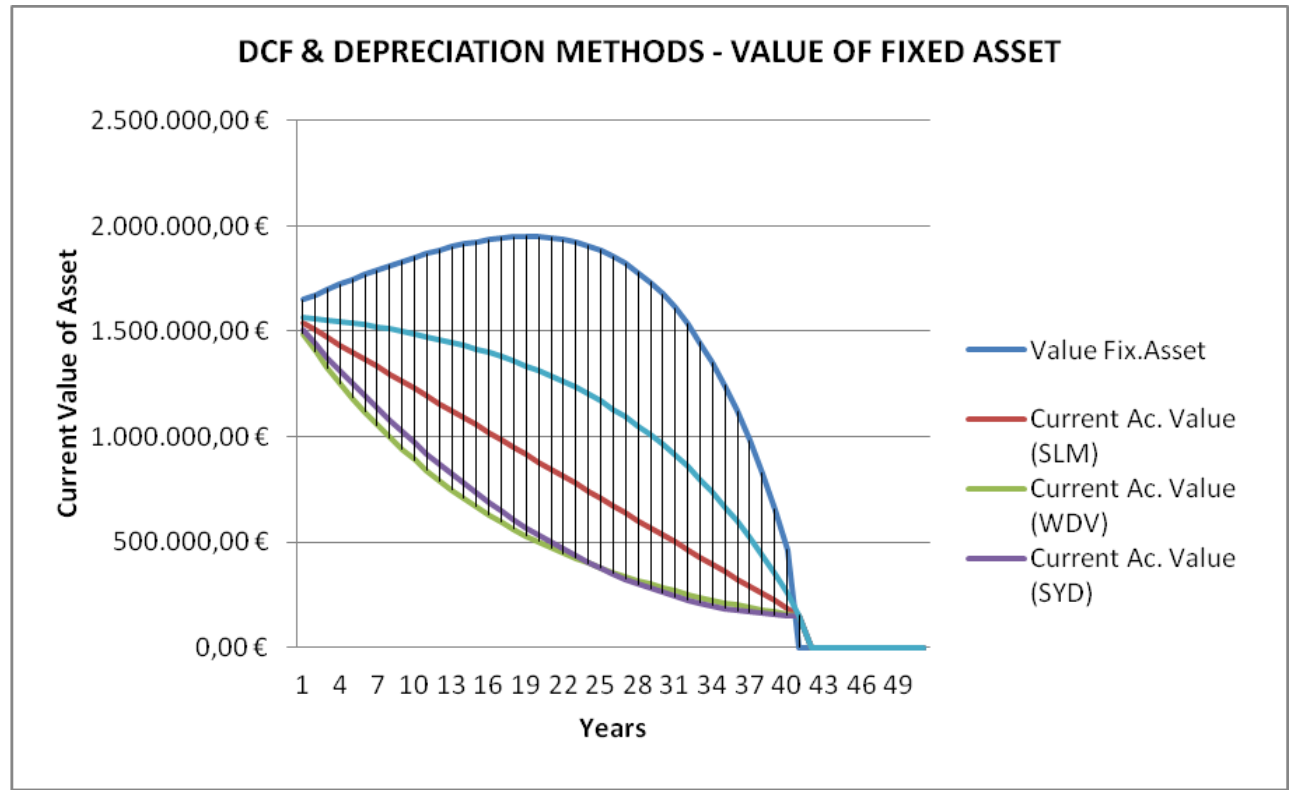

Figure 1. Fixed Asset Value curves vs. Depreciation Methods used - Office Building

During the whole useful-life of the fixed asset, its value is being recorded at any time with different values depending on the accounting principles and policies adopted as well as the depreciation methods used.

\section{CONCLUSION}

In this work, the accounting framework of tangible assets using IFRS and US GAAP and the depreciation methods together with fair value accounting following DCF methodology are examined. The DCF valuation method with the main depreciation methods are being tested for a commercial real property asset. The contribution of the paper consists of: a framework of good practices in tangible assets' management building upon the assertion that DCF methodology is fundamental for securing best value for money on property valuation; a literature review (IFRS and US GAAP principles and accounting standards for fixed assets); a literature review for depreciations methods; a critical perspective of the used accounting depreciation frameworks, providing a comparison of each framework against DCF analysis. Fixed asset management is not an easy case. Management of the firm must 'confront' several difficult issues when acquiring an asset, such as the classification, the valuation method and measurement, the monitoring, the depreciation of its value and the effects of each decision, relating to fixed assets, in the income statement and shareholders' equity. Depreciation as an accounting practice has the same point of view with DCF method. Thus, cost accounting and depreciation methods and the fair 
value accounting following DCF are facing the same problem, the time value of tangible assets.

The results of the empirical analysis indicate that the most appropriate method of depreciation is the Sinking Fund Method which is based on a financial approach to depreciated assets only when the asset is profitable. Generally, during the whole useful-life of the fixed asset, its value is being recorded at any time with different values depending on the accounting principles and policies adopted as well as the depreciation methods used.

From a practical point of view, this paper contributes to the construction of an automated mechanism for the valuation and depreciation of a fixed asset assisting in decision-making for the management of tangible assets.

\section{References}

Aston Manor Academy (2012), Fixed Asset \& Depreciation, Adopted April 2012.

Dietrich, J. R., Harris, M. S., and Muller, K. A. (2001). The reliability of investment property fair value estimates. Journal of Accounting and Economics, 30(2), 125-158.

FAS Manual Depreciation (2013), State of Idaho FAS Fixed Asset System, Rev. Date: 25/11/2013.

Financial Accounting Standards Board (2008). SFAS 144 Impairment of Long lived assets SFAS 151 Inventory Costs, SFAS 157 Fair Value Measurements, SFAS 98 Accounting for Leases.

Freshfields Bruckhaus Deringer LLP (2009). Recent changes to fair-value accounting under US GAAP and IFRS, January.

Herrmann, D., Saudaragan, S.M. and Thomas, W.B. (2006). The quality of fair value measures for property, plant, and equipment. Elsevier Accounting Forum, 30, 43-59.

International Accounting Standards Board (2008). International Financial Reporting Standards (IFRS ${ }^{\circ}$ ) including International Accounting Standards (IASs TM) and interpretations as at 1 January 2008. International Accounting Standard No. 16. Property, plant, and equipment. International Accounting Standard No. 2. Inventories. International Accounting Standard No. 17. Leases. International Accounting Standard No. 20. Accounting for Government Grants and Disclosure of Government Assistance. International Accounting Standard No. 36. Impairment of assets. International Accounting Standard No. 40. Investment Property.

International Accounting Standards Board Exposure Draft, (2009), Fair Value Measurement, May.

International Valuation Standards (2007).

Liapis, K.J., Kantianis, D.D. and Galanos, C.L. (2014), 'Commercial property whole-life costing and the taxation environment', Journal of Property Investment \& Finance, 32 (1), pp. 56-77.

Lin, Y. C. and Peasnell, K. V. (2000) Fixed asset revaluation and equity depletion in the UK, Journal of Business Finance and Accounting, 27(2/3), pp. 161-182.

Missonier-Piera, F., (2007). Motives for fixed-asset revaluation: An empirical analysis with Swiss data. The International Journal of Accounting, 42, 186-205.

Peterson, Raymond H. (2002), Accounting for Fixed Assets, 2nd Ed., John Wiley \& Sons, Inc. New York. 
Fair Value and cost accounting, depreciation methods, recognition and measurement for fixed assets

Thalassinos, E., and Liapis, K. (2013). A Comparative Analysis for the Accounting Reporting of. Employee benefits" between IFRS and other Accounting Standards: A Case Study for the Biggest Listed Entities in Greece", American Journal of Economics and Business Administration, 5(4), 153-167.

Thalassinos, I.E., Thalassinos, E.P. and Yordanov, V. (2015), "Currency Board Arrangement Capital Structure Macrofinancial Diagnostics", (June 28). Financial Management Association, Nashville, Tennessee, Annual Meeting, 2014. Available at SSRN: http://ssrn.com/abstract=2624333 or http://dx.doi.org/10.2139/ssrn.2624333

Watts, R. (2003) Conservatism in accounting - Part I: explanations and implications, Accounting Horizons, 17(3), pp. 207-222. 